\title{
Clinical considerations on the introduction of ocrelizumab in Mexico
}

\author{
Laura Ordoñez-Boschetti ${ }^{*}$, Merced Velázquez-Quintana², Eli Skromne-Eisenberg ${ }^{3}$, Irene Treviño-Frenk \\ Verónica Rivas-Alonso ${ }^{5}$, Brenda Bertado-Cortes ${ }^{6}$, Manuel De la Maza-Flores ${ }^{7}$, Sandra Quiñones-Aguilar ${ }^{8}$, \\ Luis Amaya-Sánchez ${ }^{9}$, Leonardo Llamas-López ${ }^{10}$, and Victor Gonzalez-Amezquita ${ }^{11}$ \\ ${ }^{1}$ Department of Neurology, Hospital Español de México, Mexico City; ${ }^{2}$ Department of Neurology, Unidad de Investigación en Salud de Chihuahua, \\ Chihuahua; ${ }^{3}$ Mexican Neuroscience Institute, Hospital Ángeles Interlomas, Mexico City; ${ }^{4}$ Multiple Sclerosis Clinic, Department of Neurology, Instituto \\ Nacional de Nutrición Salvador Zubirán (INNSZ), Mexico City; ${ }^{5}$ Multiple Sclerosis Clinic, Department of Neurology, Instituto Nacional de Neurología \\ y Neurocirugía Doctor Manuel Velasco Suárez (INNNMVS), Mexico City; ${ }^{6}$ Multiple Sclerosis Clinic, Department of Neurology, Centro Médico \\ Nacional Siglo XXI, Instituto Mexicano del Seguro Social (IMSS), Mexico City; ${ }^{7}$ Department of Neurology, Hospital San José, Instituto Tecnológico \\ de Estudios Superiores de Monterrey (ITESM), Neurology and Neurosurgery Institute, Hospital Zambrano Hellion, Monterrey, Nuevo León; \\ ${ }^{8}$ Demyelinating Diseases Clinic, Department of Neurology, Centro Médico Nacional Siglo XXI, Instituto Mexicano del Seguro Social (IMSS), Mexico \\ City; ${ }^{9}$ Department of Neurology, Centro Médico Nacional Siglo XXI, Instituto Mexicano del Seguro Social (IMSS), Mexico City; ${ }^{10}$ Department of \\ Neurology, Hospital Valentín Gómez Farías, Instituto de Seguridad y Servicios Sociales de los Trabajadores del Estado (ISSSTE), Guadalajara, \\ Jalisco; ${ }^{11}$ Department of Neurology, Instituto de Seguridad Social del Estado de México y Municipios (ISSEMyM), Toluca, State of Mexico, Mexico
}

\begin{abstract}
Multiple sclerosis (MS) is the leading cause of neurological disability among young adults. The disease-modifying treatments (DMTs) have been a breakthrough in the care of this patients, becoming a treatable disease. Today, we face a broad spectrum of treatment possibilities, which should be used rationally to provide the maximum benefit for the patients. In the context of the introduction of ocrelizumab as a treatment option in the Mexican MS DMT portfolio, a group of neurologists was convened to analyze the potential transition among DMT from their experience, through a desk research and expert opinion. As a result, here we describe the different considerations suggested for switching from different DMT to ocrelizumab that includes profiling studies, washout periods, and follow-up considerations. We concluded that the switch from other DMT previously used to ocrelizumab could be convenient and safe, as long as there is an adequate selection and profiling of the patients.
\end{abstract}

Key words: Drug switching. Expert opinion. Mexico. Multiple sclerosis. Ocrelizumab. Disease-modifying treatment.

\section{Consideraciones clínicas sobre la introducción del ocrelizumab en México}

\section{Resumen}

La esclerosis múltiple (EM) es la principal causa neurológica de discapacidad en adultos jóvenes. Los tratamientos modificadores de la enfermedad (TME) han representado un enorme avance en su atención y han convertido a la EM en una enfermedad tratable. Hoy día nos enfrentamos a un amplio espectro de posibilidades de tratamientos, que deben ser utilizados de forma racional para brindar el mayor beneficio a los pacientes. En el contexto de la introducción del ocrelizumab al mercado mexicano se convocó a un grupo de neurólogos con el fin de analizar la transición terapéutica desde

\section{Correspondence:}

*Laura Ordoñez-Boschetti

E-mail: dra.ordonezboschetti@gmail.com
Available online: 18-05-2020

Rev Mex Neuroci. 2020;21(3):97-103

www.revmexneurociencia.com 1665-5044/ @ 2020 Academia Mexicana de Neurología A.C. Published by Permanyer. This is an open access article under the CC BY-NC-ND license (http://creativecommons.org/licenses/by-nc-nd/4.0/). 
diferentes ópticas, con base en la experiencia del grupo convocado con el uso de TME, realizando una investigación documental y de opinión de expertos. Como resultado se describen los diferentes aspectos para considerar el cambio de diferentes moléculas previamente usadas a ocrelizumab, así como los estudios de perfilamiento sugeridos, el tiempo de eliminación para cada molécula, los tiempos de lavado necesarios para cada molécula y los estudios de seguimiento necesarios. Se concluye que el cambio de las TME presentes a ocrelizumab puede resultar conveniente y seguro, siempre $y$ cuando exista una adecuada selección y perfilamiento de los pacientes.

Palabras clave: Cambio de tratamiento. Esclerosis múltiple. México. Ocrelizumab. Opinión de expertos. Tratamiento modificador de la enfermedad.

\section{Introduction}

Multiple sclerosis (MS) is the main neurological cause of disability in young adults around the world. The diagnosis of MS has increased substantially in the past few decades, with a prevalence of $1.6 / 100,000$ habitants in $1972^{1,2}$. According to the previous studies, it has been estimated that there are at least 15,000 people in Mexico who suffer from MS, with a prevalence of 7.5-30/100,000 habitants ${ }^{2,3}$.

Treatment aimed at modifying the natural history of MS has progressed considerably. The first disease-modifying treatment (DMT) approved was interferon beta- $1 \mathrm{~b}$ in $1993^{1}$, since then, we have had major changes in the understanding of the disease and now much more is known about environmental risk factors and genetic susceptibly, and the specific pathogenesis of MS may be explained in more detail. That is why there is now a wide range of treatment options available that should be used rationally to better benefit patients ${ }^{3}$.

This work was carried out in the context of the introduction of ocrelizumab (Ocrevus ${ }^{\circledR}$ ) to the Mexican market. Ocrelizumab is an IgG1 humanized monoclonal antibody that depletes B lymphocytes that express the CD20+ surface protein in their membrane. This limits immunological events linked to autoimmune conditions, specifically, $\mathrm{MS}^{4}$. Having a new DMT available, make it possible to debate over its use, which is why Roche has brought together a group of Mexican neurologists to examine the therapeutic transition from different points of view, based on their experience. The opinions given herein are the responsibility of the physicians who gave them and are independent from the unrestricted support given.

This work was carried out before ocrelizumab was available in Mexico; the health authorities have given the authorization to commercialize it.

\section{Materials and methods}

This analysis was carried out in the second half of 2017. Eleven neurologists considered as opinion leaders in MS, highly experienced in DMT and its mechanism of action (MoA), who understood the implications of changing treatment and were asked to give their point of view.

The group was made up of 11 neurologists who worked at some of the major public and private health institutions and hospitals in Mexico (INNN, IMSS, Hospital Español, Hospital Ángeles Lomas, INCNSZ, ISSSTE, ISSEMyM, etc.)

The work was carried out in two hands-on sessions, each lasting 2 days. Points to be considered included: (a) defining the guidelines for the proper use of ocrelizumab; (b) establishing the medical reasons for why a switch in treatment could be considered and its implications; (c) suggested paraclinical studies according to the treatment from which they are switching; (d) suggested washout period to migrate each DMT to ocrelizumab; and (e) suggested paraclinical control studies.

The work has been carried out for academic purposes, design as a non-experimental and documentary research that involved open discussion in teams and reflections as a group.

The work was divided into two sessions: in the first, the group was divided into teams to discuss in depth of rationale behind each subject and reach a consensus; in the second, all proposals were discussed extensively followed by an open discussion on what was learned and final comments and consensus.

\section{Results}

Placing ourselves in the MS treatment algorithm context, in Mexico, we have beta-1b interferon, beta-1a interferon, glatiramer acetate, teriflunomide, dimethyl fumarate, fingolimod, natalizumab, and alemtuzumab. Ocrelizumab is now one of the many drugs available.

Treatment guidelines around the world say that the choice of DMT depends on the characteristics of patients, comorbidities, activity/severity of the disease, safety profile, access to treatment, and other aspects $^{5-7}$. 
Table 1. Recommendations to switch from an oral disease-modifying treatment to ocrelizumab

\begin{tabular}{|c|c|c|c|}
\hline Consideration & Teriflunomide $^{9-11}$ & Dimethyl fumarate ${ }^{12-15}$ & Fingolimod ${ }^{14,16-20}$ \\
\hline $\begin{array}{l}\text { MoA to consider } \\
\text { before switching }\end{array}$ & $\begin{array}{l}\text { Inhibits the mitochondrial } \\
\text { DHO-DH enzyme selectively } \\
\text { and reversibly; reduces rapid } \\
\text { replication of lymphocytes; } \\
\text { blocks proliferation of the } \\
\text { activated T and B lymphocytes } \\
\text { Enterohepatic recycling } \\
\text { The accelerated elimination } \\
\text { process may be used, if } \\
\text { necessary }\end{array}$ & $\begin{array}{l}\text { Reduces oxidative stress and } \\
\text { inhibits pro-inflammatory cytokines, } \\
\text { causing lymphopenia }\end{array}$ & $\begin{array}{l}\text { As it is a functional antagonist of the S1P } \\
\text { receptor, it blocks the capability of } \\
\text { lymphocytes to exit the lymph nodes, } \\
\text { causing lymphopenia. Specifically, the } \\
\text { MoA to be considered on circulating B } \\
\text { cells is the potential decrease in } \\
\text { activated B memory cells (CD38) }\end{array}$ \\
\hline $\begin{array}{l}\text { Possible } \\
\text { switching } \\
\text { scenarios }\end{array}$ & $\begin{array}{l}\text { No response to treatment } \\
\text { (clinical activity and/or in } \\
\text { MRI) after } 6 \text { months of } \\
\text { continuous use and having } \\
\text { checked adherence to } \\
\text { treatment } \\
\text { Patients who do not adhere } \\
\text { to or are intolerant to } \\
\text { treatment } \\
\text { Inherent adverse effects of } \\
\text { teriflunomide } \\
\text { Choice of patient because of } \\
\text { convenience of dose }\end{array}$ & $\begin{array}{l}\text { No response to treatment (clinical } \\
\text { activity and/or in MRI) after } 6 \\
\text { months of continuous use and } \\
\text { having checked adherence to } \\
\text { treatment } \\
\text { Patients who do not adhere to } \\
\text { treatment because of dosage } \\
\text { Adverse events of DMF that makes } \\
\text { it difficult to continue treatment } \\
\text { Choice of patient in dosage due to } \\
\text { convenience }\end{array}$ & $\begin{array}{l}\text { No response to treatment (clinical } \\
\text { activity and/or in MRI) after } 6 \text { months of } \\
\text { continuous use and having checked } \\
\text { adherence to treatment. Patients who do } \\
\text { not adhere to treatment } \\
\text { Adverse events of fingolimod that makes } \\
\text { it difficult to continue treatment } \\
\text { Choice of patient in dosage due to } \\
\text { convenience } \\
\text { In patients who do not respond after } \\
\text { switching from natalizumab to Fingolimod } \\
\text { due to the risk of PML. Literature reports } \\
\text { positive outcomes switching to anti-CD20 } \\
\text { therapy }\end{array}$ \\
\hline $\begin{array}{l}\text { Additional } \\
\text { screening }\end{array}$ & $\begin{array}{l}\text { Standard screening } \\
\text { previously described for } \\
\text { ocrelizumab, including } \\
\text { pregnancy test } \\
\text { If needed serum level of } \\
\text { teriflunomide }\end{array}$ & $\begin{array}{l}\text { Standard screening previously } \\
\text { described for ocrelizumab, } \\
\text { including pregnancy test }\end{array}$ & $\begin{array}{l}\text { Standard screening previously described } \\
\text { for ocrelizumab } \\
\text { Rule out chicken pox } \\
\text { Rule out skin cancer and breast cancer } \\
\text { in patients at risk } \\
\text { Anti-JCV antibody index recommended, } \\
\text { as we are aware that there have been } \\
\text { reported cases of PML associated with } \\
\text { fingolimod treatment }{ }^{19}\end{array}$ \\
\hline Washout time & $\begin{array}{l}\text { Immediate if all screening } \\
\text { paraclinics are normal } \\
\text { If there is an alteration to the } \\
\text { liver function } \\
\text { If lymphocytes are below } \\
\text { normal limits, consider } \\
\text { accelerated elimination } \\
\text { Consider induced washout } \\
\text { with activated carbon or } \\
\text { cholestyramine }\end{array}$ & $\begin{array}{l}\text { It is recommended to wait for total } \\
\text { lymphocyte recovery and, ideally, } \\
\text { measure sub-populations of } \\
\text { lymphocytes by flow cytometry, and } \\
\text { check status of liver function tests. } \\
\text { If the parameters are normal, you } \\
\text { may switch immediately } \\
\text { A washout time of } 6-12 \text { weeks is } \\
\text { recommended depending on recovery } \\
\text { of lymphocytes and liver function tests }\end{array}$ & $\begin{array}{l}\text { Given the MoA, } 6-12 \text { weeks are } \\
\text { recommended. It is important to check } \\
\text { recovery of total lymphocyte count (at } \\
\text { least } 800 \text { cell/ml) in blood count and, } \\
\text { ideally, measure sub-populations of } \\
\text { lymphocytes by flow cytometry }\end{array}$ \\
\hline $\begin{array}{l}\text { Monitoring when } \\
\text { switching to } \\
\text { ocrelizumab }\end{array}$ & $\begin{array}{l}\text { Monitor disease's activity } \\
\text { (EDSS and MRI) every } 6 \\
\text { months }\end{array}$ & $\begin{array}{l}\text { Monitor disease's activity (EDSS } \\
\text { and MRI) every } 6 \text { months } \\
\text { Lymphocyte count } \\
\text { Monitor liver function } \\
\text { Convenience of whether to carry } \\
\text { out anti-JVC antibodies or not is } \\
\text { still in debate }\end{array}$ & $\begin{array}{l}\text { Monitor disease's activity (EDSS and } \\
\text { MRI) every } 6 \text { months } \\
\text { Lymphocyte count } \\
\text { Monitor cancer } \\
\text { Convenience of whether to carry out } \\
\text { anti-JVC antibodies or not is still in } \\
\text { debate }\end{array}$ \\
\hline
\end{tabular}

DHO-DH: dihydroorotate dehydrogenase, MRI: magnetic resonance imaging, EDSS: expanded disability status scale, DMF: dimethyl fumarate, JVC: JC virus, MoA: mechanism of action, PML: progressive multifocal leukoencephalopathy, S1P: sphingosine-1-phosphate.

The following aspects were analyzed as part of the work to consider switching from other DMT to ocrelizumab:

a. The MoA to be considered and its clinical implications

b. The most relevant safety and efficacy considerations of each DMT for which a switch may be needed c. Elimination time of the previous DMT from which the switch is made and, therefore, washout time, if necessary. Paraclinical studies before the switch is made

d. Paraclinical follow-up studies to monitor safety 
Table 2. Recommendations to switch from a monoclonal antibody group disease-modifying treatment to ocrelizumab

\begin{tabular}{|c|c|c|c|}
\hline Consideration & Natalizumab $b^{8,16,20}$ & Alemtuzumab ${ }^{20-24}$ & Rituximab $^{16,26}$ \\
\hline $\begin{array}{l}\text { MoA to be considered } \\
\text { before switching }\end{array}$ & $\begin{array}{l}\text { Humanized } \alpha 4 \text {-integrin antagonist } \\
\text { mAb, inhibiting migration of } \\
\text { lymphocytes through the blood-brain } \\
\text { barrier. Its MoA should be } \\
\text { considered when switching } \\
\text { treatment due to the risk of IRIS }\end{array}$ & $\begin{array}{l}\text { Anti-CD52 mAb that depletes T and B } \\
\text { lymphocytes. The effect of alemtuzumab } \\
\text { on B cells may be transitory and there } \\
\text { may be an early rebound, so anti-CD20 } \\
\text { would be a suitable option }\end{array}$ & Anti-CD20 mAb \\
\hline $\begin{array}{l}\text { Possible switching } \\
\text { scenarios }\end{array}$ & $\begin{array}{l}\text { No response to treatment (clinical } \\
\text { activity and/or in MRI) after } 6 \text { months } \\
\text { of continuous use and having } \\
\text { checked adherence to treatment. } \\
\text { Risk of PML in patients with }>24 \\
\text { infusions of natalizumab and/or a } \\
\text { high JCV index } \\
\text { Patients who do not adhere to } \\
\text { treatment } \\
\text { Adverse effects of natalizumab that } \\
\text { makes it difficult to continue } \\
\text { treatment } \\
\text { Choice of patient because of } \\
\text { convenience of dose }\end{array}$ & $\begin{array}{l}\text { Disease activity (clinical and/or } \\
\text { radiological) after the } 2^{\text {nd }} \text { year of } \\
\text { treatment } \\
\text { Reconstitution syndrome measured by B } \\
\text { lymphocytes; it is recommended to } \\
\text { check sub-populations of lymphocytes } \\
\text { by flow cytometry } \\
\text { Adverse effects that make it difficult to } \\
\text { continue with infusions (incomplete } \\
\text { cycles) } \\
\text { Choice of patient } \\
\text { Patients in transitional/progressive } \\
\text { disease. Approved as therapy for active } \\
\text { secondary progressive and PPMS in } \\
\text { adults by the FDA. Consider the local } \\
\text { labeling in Mexico is approved for RMS } \\
\text { and PPMS }\end{array}$ & $\begin{array}{l}\text { Adverse reactions } \\
\text { (infusion related) } \\
\text { Off-label use may limit } \\
\text { insurance approval }\end{array}$ \\
\hline Additional screening & $\begin{array}{l}\text { Anti-JCV antibody titers } \\
\text { recommended, particularly in } \\
\text { patients who switch due to the risk } \\
\text { of PML } \\
\text { MRI no > } 3 \text { weeks, with FLAIR/T2, } \\
\text { DWI sequence to discard PML } \\
\text { Monitoring MRI every } 3 \text { months } \\
\text { during the } 1^{\text {st }} \text { year to asses risk of } \\
\text { PML } \\
\text { Rule out syphilis and chicken pox }\end{array}$ & $\begin{array}{l}\text { Lymphocyte count, considering flow } \\
\text { cytometry to measure cell sub- } \\
\text { populations, bearing in mind that } \\
\text { immunosuppression in these patients is } \\
\text { greater } \\
\text { Tests to rule out cancer (mastography, } \\
\text { papanicolaou, APE, SOH, skin cancer) } \\
\text { Tests to rule out other autoimmune } \\
\text { conditions } \\
\text { Consider prophylaxis with acyclovir, } \\
\text { TMP-SMX }\end{array}$ & $\begin{array}{l}\text { If profiling carried out } \\
\text { previously for } \\
\text { rituximab, continue } \\
\text { with routine monitoring }\end{array}$ \\
\hline Washout time & $\begin{array}{l}\text { 4-12 weeks, discarding lesions } \\
\text { suggestive of PML by MRI. Risk of } \\
\text { IRIS should be taken into account }\end{array}$ & At least 6 months after the last infusion & $\begin{array}{l}\text { Unnecessary, should } \\
\text { continue with } \\
\text { application scheme } \\
\text { established (every } 6 \\
\text { months) }\end{array}$ \\
\hline $\begin{array}{l}\text { Monitoring when } \\
\text { switching to } \\
\text { ocrelizumab }\end{array}$ & $\begin{array}{l}\text { Monitor disease activity (EDSS and } \\
\text { MRI) every 6-12 months } \\
\text { Monitor PML data up to } 6 \text { months } \\
\text { after latest infusion of de } \\
\text { natalizumab } \\
\text { Lymphocyte counts } \\
\text { Monitoring cancer } \\
\text { Convenience of carrying out anti-JCV } \\
\text { antibodies questioned once again }\end{array}$ & $\begin{array}{l}\text { Monitor disease activity (EDSS and MRI) } \\
\text { checking patient's stability } \\
\text { Lymphocyte count } \\
\text { Monitoring cancer, including skin } \\
\text { cancer } \\
\text { Continue monitoring alemtuzumab's } \\
\text { potential side effects for } 5 \text { years }\end{array}$ & $\begin{array}{l}\text { Monitor disease } \\
\text { activity (EDSS and } \\
\text { MRI) every } 1-12 \text { months } \\
\text { Lymphocyte counts } \\
\text { Monitoring cancer }\end{array}$ \\
\hline Evidence & $\begin{array}{l}\text { Literature reports improved efficacy } \\
\text { results in patients who switched } \\
\text { from natalizumab to anti- CD20 } \\
\text { treatment versus oral DMT }\end{array}$ & $\begin{array}{l}\text { Cases have been reported in literature } \\
\text { of patients not responding to } \\
\text { alemtuzumab who benefited from } \\
\text { switching to anti-CD20 therapy } \\
\text { Anti-CD20 therapy has been used in } \\
\text { cases of early B lymphocyte } \\
\text { reconstitution rebound }\end{array}$ & Still no evidence \\
\hline
\end{tabular}

MoA: mechanism of action, IRIS: immune reconstitution inflammatory syndrome, mAb: monoclonal antibodies, MRI: magnetic resonance imaging, DMT: disease-modifying treatment, PPMS: primary progressive multiple sclerosis, PML: progressive multifocal leukoencephalopathy, JCV: JC virus, FLAIR: fluid-attenuated inversion recovery, DWI: diffusion-weighted imaging, EDSS: expanded disability status scale, FDA: Food and Drug Administration. 
In every case, the suggested paraclinical studies for patients to start treatment with ocrelizumab include the following:

- Blood count

- Blood chemistry

- Liver function tests

- Hepatitis testing - surface antigen and anti-core antibodies of the virus (AgHBVs and anti-HBVc).

- Rule out tuberculosis - recommend for the population exposed.

- Rule out HIV- recommend for the population exposed.

- Magnetic resonance imaging (MRI) - it is recommended to have a baseline MRI of no more than 3 weeks ${ }^{8}$, ruling out any suspected progressive multifocal leukoencephalopathy. The following sequences must be taken into consideration: T1, T1 with gadolinium, T2, and fluid-attenuated inversion recovery, according to the international standard recommended by the MAGNIMS group ${ }^{8}$. The frequency and make-up of each follow-up is determined by the needs of the individual patient ${ }^{8}$.

If switching from other DMT, specific recommended studies may be added based on what is known about the MoA, as shown in tables 1 and 2. Therapies were divided into two large DMT groups: (a) oral DMT and (b) monoclonal antibodies (mAb). The tables below summarize the considerations made in the discussion groups.

We should point out that there is currently not enough evidence to draw final conclusions, so in this study, we will look at recommendations based on evidence available of the MoA and the recommendations to switch from each DMT. The vast experience of clinical neurologists in using innovative DMT for MS was taken into account.

\section{Conclusions}

Some 25 years after the introduction of the first interferon for treating MS, we have witnessed how DMT has evolved, aiming to adjust the pathological processes of this disease that we understand better than before. We are well aware that there is no single treatment algorithm and decisions should be made based on the knowledge of the MoA and the experience gained with these therapies.

When discussing DMT, we may classify its development in three eras: (i) from 1993 to 2003, when the first interferons were introduced and drugs were developed to better understand the immune physiopathological process of MS; (ii) the second was from 2003 to 2009 with the advent of more efficacious DMT, such as natalizum$a b$, the first monoclonal antibody, and fingolimod, the first oral DMT; and (iii) the third from 2009 to date, in which not only were biological therapies developed but also small molecules, such as dimethyl fumarate. The range of MoA from the DMT has been expanded during this time, the results are encouraging ${ }^{27}$.

Bearing this in mind, it is of particular interest to reflect on the experience and opinions of clinical neurologists about the potential switching from other DMT to those recently approved, such as ocrelizumab.

The group concludes that the switch of current DMT to ocrelizumab may be convenient and safe, as long as the patients are selected and evaluated correctly. We should bear in mind that the patients should be monitored closely during the first $24 \mathrm{~h}$ after the switch.

Real-life evidence is needed by means of several cases and evidence of safety in the medium and long term.

\section{Ethical declaration}

This work was carried out with the unrestricted support of Roche de México, including transport, travel expenses, and the fees of each person attending meetings.

\section{Acknowledgments}

The authors would like to thank Drs. Maria Pia Roque, Mariana Arzate, Roxana Flores, Carlos Pla, and Asdrubal Huerta of Roche México for assisting in the logistics of the activities carried out and Dr. Jose de Jesus Flores Rivera for his support.

\section{Conflicts of interest}

Dr. Ordoñez reports personal fees and non-financial support from Roche Servicios de Mexico, during the conduct of the study, personal fees and non-financial support from Novartis, personal fees and non-financial support from Stendhal, personal fees and non-financial support from Teva, personal fees and non-financial support from Sanofi, personal fees and non-financial support from Mer$c k$, grants and personal fees from Biogen, and grants and personal fees from Synthon, outside the submitted work; Dr. Velazquez Quintana reports personal fees and non-financial support from Roche Servicios de Mexico, during the conduct of the study; Dr. Skromne Eisenberg reports personal fees and non-financial support from Roche Servicios de Mexico, during the conduct of the study, personal fees and non-financial support from Merck, personal 
fees and non-financial support from Sanofi, personal fees and non-financial support from Stendhal, personal fees and non-financial support from Teva, and personal fees and non-financial support from Biogen, outside the submitted work; Dr. Treviño Frenk reports personal fees and non-financial support from Roche Servicios de Mexico, during the conduct of the study, personal fees and non-financial support from Teva, personal fees and non-financial support from Novartis, personal fees and non-financial support from Stendhal, personal fees and non-financial support from Merck, and personal fees and non-financial support from Sanofi, outside the submitted work; Dr. Rivas Alonso reports personal fees and non-financial support from Roche Servicios de Mexico, during the conduct of the study, personal fees and non-financial support from Stendhal, personal fees and non-financial support from Novartis, personal fees and non-financial support from Sanofi, personal fees and non-financial support from Biogen, personal fees and non-financial support from Allegran, personal fees and non-financial support from Merck, personal fees and non-financial support from Psicofarma, personal fees and non-financial support from Allegran, and personal fees and non-financial support from Actellion, outside the submitted work; Dr. Bertado Cortes reports personal fees and non-financial support from Roche Servicios de Mexico, during the conduct of the study, personal fees and non-financial support from Novartis, personal fees and non-financial support from Teva, personal fees and non-financial support from Stendhal, personal fees and non-financial support from Sanofi, personal fees and non-financial support from Merck, and personal fees and non-financial support from Biogen, outside the submitted work; Dr. De La Maza Flores reports personal fees and non-financial support from Roche Servicios de Mexico, during the conduct of the study, personal fees and non-financial support from Novartis, personal fees and non-financial support from Sanofi, and personal fees and non-financial support from Merck, outside the submitted work; Dr. Quiñones Aguilar reports personal fees and non-financial support from Roche Servicios de Mexico, during the conduct of the study, personal fees and non-financial support from Novartis, personal fees and non-financial support from Sanofi, personal fees and non-financial support from Biogen, personal fees and non-financial support from Merck, personal fees and non-financial support from Teva, personal fees and non-financial support from Allegran, and personal fees and non-financial support from Dysport, outside the submitted work; Dr. Amaya Sanchez reports personal fees and non-financial support from Roche Servicios de Mexico, during the conduct of the study, personal fees and non-financial support from Novartis, personal fees and non-financial support from Sanofi, and personal fees and non-financial support from Bayer, outside the submitted work; Dr. Llamas Lopez reports personal fees and non-financial support from Roche Servicios de Mexico, during the conduct of the study, personal fees and non-financial support from Biogen, personal fees and non-financial support from Merck, personal fees and non-financial support from Novartis, personal fees and non-financial support from Teva, personal fees and non-financial support from Stendhal, and grants from Probiomedic, outside the submitted work; and Dr. Gonzalez Amezquita reports personal fees and non-financial support from Roche Servicios de Mexico, during the conduct of the study, personal fees and non-financial support from Bayer, personal fees and non-financial support from Merck, personal fees and non-financial support from Sanofi, personal fees and non-financial support from Stendhal, personal fees and non-financial support from UCB, personal fees and non-financial support from Probiomedic, personal fees and non-financial support from Armstron, personal fees and non-financial support from Allegran, and personal fees and non-financial support from Merz, outside the submitted work.

\section{Ethical disclosures}

Protection of human and animal subjects. The authors declare that no experiments were performed on humans or animals for this study.

Confidentiality of data. The authors declare that no patient data appear in this article.

Right to privacy and informed consent. The authors declare that no patient data appear in this article.

\section{References}

1. Tillery EE, Clements JN, Howard Z. What's new in multiple sclerosis? Ment Health Clin. 2017;7:213-20.

2. Velazquez M, Lopez P, Rivera C. Características epidemiológicas de la esclerosis múltiple en un estado fronterizo con los Estados Unidos de Norteamérica. Arch Neurocie. 2002;3:147-50.

3. Correa E, Paredes V, Martínez B. Prevalence of multiple sclerosis in Latin America and its relationship with European migration. Mult Scler $\mathrm{J}$ Exp Transl Clin. 2016;2:1-10.

4. Frau J, Coghe G, Lorefice L, Fenu G, Cocco E. New horizons for multiple sclerosis therapeutics: milestones in the development of ocrelizumab. Neuropsychiatr Dis. Treat 2018;14:1093-9.

5. Soelberg Sorensen P. Safety concerns and risk management of multiple sclerosis therapies. Acta Neurol Scand. 2017;136:168-86

6. Rae-Grant A, Day GS, Marrie RA, Rabinstein A, Cree BAC, Gronseth GS, et al. Practice guideline recommendations summary: disease-modifying therapies for adults with multiple sclerosis: report of the Guideline Development, Dissemination, and Implementation Subcommittee of the American Academy of Neurology. Neurology. 2018;90:777-88.

7. Wattjes MP, Rovira À, Miller D, Yousry TA, Sormani MP, de Stefano MP, et al. Evidence-based guidelines: MAGNIMS consensus guidelines on the use of MRI in multiple sclerosis--establishing disease prognosis and monitoring patients. Nat Rev Neurol. 2015;11:597-606. 
8. Montalban X, Gold R, Thompson AJ, Otero-Romero S, Amato MP, Chandraratna $D$, et al. ECTRIMS/EAN guideline on the pharmacological treatment of people with multiple sclerosis. Eur J Neurol. 2018; 25:215-37.

9. Miller AE. Oral teriflunomide in the treatment of relapsing forms of multiple sclerosis: clinical evidence and long-term experience. Ther Adv Neurol Disord. 2017:10:381-96.

10. O'Connor P, Comi G, Freedman MS, Miller AE, Kappos L, Bouchard JP, et al. Long-term safety and efficacy of teriflunomide: nine-year follow-up of the randomized TEMSO study. Neurology. 2016;86:920-30.

11. Gandoglia I, Ivaldi F, Laroni A, Benvenuto F, Solaro C, Mancardi G, et al. Teriflunomide treatment reduces $B$ cells in patients with MS. Neurol Neuroimmunol Neuroinflamm. 2017;4:e403.

12. Zhovtis Ryerson L, Green R, Confident G, Pandey K, Richter B, Bacon T, et al. Efficacy and tolerability of dimethyl fumarate in White-, African- and Hispanic- Americans with multiple sclerosis. Ther Adv Neurol Disord. 2016;9:454-61.

13. Chen H, Assmann JC, Krenz A, Rahman M, Grimm M, Karsten CM, et al. Hydroxycarboxylic acid receptor 2 mediates dimethyl Fumarate's protective effect in EAE. J Clin Invest 2014;124:2188-92.

14. Hersh CM, Love TE, Cohn S, Hara-Cleaver C, Bermel RA, Fox RJ, et al. Comparative efficacy and discontinuation of dimethyl fumarate and fingolimod in clinical practice at 12-month follow-up. Mult Scler Relat Disord. 2016;10:44-52.

15. Fox RJ, Kita M, Cohan SL, Henson LJ, Zambrano J, Scannevin RH, et al. BG-12 (dimethyl fumarate): a review of mechanism of action, efficacy, and safety. Curr Med Res Opin. 2014;30:251-62.

16. Alping P, Frisell T, Novakova L, Islam-Jakobsson P, Salzer J, Björck A, et al. Rituximab versus fingolimod after natalizumab in multiple sclerosis patients. Ann Neurol. 2016;79:950-8.
17. Angerer IC, Hecker M, Koczan D, Roch L, Friess J, Rüge A, et al. Transcriptome profiling of peripheral blood immune cell populations in multiple sclerosis patients before and during treatment with a sphingosine-1-phosphate receptor modulator. CNS Neurosci Ther 2018;24:193-201.

18. Nakamura M, Morris M, Cerghet M, Schultz L, Elias S. Longitudinal follow-up of a cohort of patients with incidental abnormal magnetic resonance imaging findings at presentation and their risk of developing multiple sclerosis. Int J MS Care. 2014;16:111-5.

19. Ingwersen J, Aktas O, Kuery P, Kieseier B, Boyko A, Hartung HP. Fingolimod in multiple sclerosis: mechanisms of action and clinical efficacy. Clin Immunol. 2012:142:15-24.

20. Berger JR. Classifying PML risk with disease modifying therapies. Mult Scler Relat Disord. 2017;12:59-63.

21. Baker D, Herrod SS, Alvarez-Gonzalez C, Giovannoni G, Schmierer K. Interpreting lymphocyte reconstitution data from the pivotal phase 3 trials of alemtuzumab. JAMA Neurol. 2017;74:961-9.

22. Haghikia A, Dendrou CA, Schneider R, Grüter T, Postert T, Matzke M, et al. Severe B-cell-mediated CNS disease secondary to alemtuzumab therapy. Lancet Neurol. 2017;16:104-6.

23. Available from: https://www.accessdata.fda.gov/drugsatfda_docs/label/2019/761053s018lbl.pdf. [Last accessed on 2020 Jan 15].

24. Kappos L, Wolinsky JS, Giovannoni G, Arnold DL, Lublin F, Wang Q, et al. Ocrelizumab reduces disability progression independent of relapse activity in patients with relapsing multiple sclerosis. Mult Scler J. 2017;23:309-10.

25. Wehrum T, Beume LA, Stich O, Mader I, Mäurer M, Czaplinski A, et al. Activation of disease during therapy with alemtuzumab in 3 patients with multiple sclerosis. Neurology. 2018;90:e601-5.

26. Hauser SL. The Charcot lecture beating MS: a story of B cells, with twists and turns. Mult Scler. 2015;21:8-21.

27. Ransohoff RM, Hafler DA, Lucchinetti CF. Multiple sclerosis-a quiet revolution. Nat Rev Neurol. 2015;11:134-42. 